CORRESPONDENCE

\title{
lodide supplementation of the anti-viral duox-lactoperoxidase activity may prevent some SARS-CoV-2 infections
}

(c) The Author(s), under exclusive licence to Springer Nature Limited 2021

European Journal of Clinical Nutrition (2022) 76:629-630; https:// doi.org/10.1038/s41430-021-00995-2

\section{TO THE EDITOR:}

SARS-CoV-2, commonly termed COVID-19, is an airborne viral agent entering humans via the nose and mouth, lodging in the lungs. Vaccines are now available to the few but will require years before billions can be immunized. Many will remain susceptible in countries which cannot afford expensive vaccines. Enforced economic shutdowns and strict social distancing cannot be sustained forever. We suggest a cheap supplement, iodide, which is available to many and may possibly dampen the rate of COVID19 infection and transmission. The protective mammalian enzyme lactoperoxidase (LPO) is extruded into human lungs and saliva [1]. It catalyzes the conversion of thiocyanate $\left(\mathrm{SCN}^{-}\right)$by hydrogen peroxide $\left(\mathrm{H}_{2} \mathrm{O}_{2}\right)$, into the product hypothiocyanite $\left(\mathrm{OSCN}^{-}\right)$in a well-known reaction [2]. LPO also catalyzes the oxidation of iodide with $\mathrm{H}_{2} \mathrm{O}_{2}$ into hypoiodite $\left(\mathrm{IO}^{-}\right)$and hypoiodous acid (HOI). Most mammals also biosynthesize the highly reactive, detrimental agent, $\mathrm{H}_{2} \mathrm{O}_{2}$ as required by LPO, by an enzyme ensemble, duox [3]. Both the $\mathrm{OSCN}^{-}$and $\mathrm{IO}^{-}$products are potent, non-specific antimicrobial agents and are lethal to the influenza virus [4]. The three-dimensional structures of the complexes of LPO with the $\mathrm{I}^{-}$ has shown this substrate has many sites including the active substrate binding site, which is even more evidence of the importance of this enzyme for production of hypoiodite [5]. The duox-LPO system is recognized as the first line of defence against airborne viral infections.

The COVID-19 infection rate is low in Japan, which despite being densely populated islands have not enforced a strict lock down. The typical Japanese diet is rich in seafood including kelp and seaweed, which are high in iodine. We note this inverse correlation between iodine intake and COVID-19 infections and think this is more than a correlation but a causal relationship. The average Japanese adult consumes more than twice the iodine than the US RDA $(150 \mu \mathrm{g})$ but still under the recommended upper daily limit of $1100 \mu \mathrm{g}$. We report here a mechanism which explains this correlation and is present in human lungs as the protective duox-LPO system. Increasing $\mathrm{I}^{-}$in mammalian airways has been shown to enhance the duox-LPO system performance and viral agent destruction [6]. Both $\mathrm{IO}^{-}$and $\mathrm{HOI}$ are non-specific, anti-viral agents so the destructive activity will be independent of the SARSCoV 2 type (mutant). COVID-19 has decimated the elderly and institutionalized. These people typically have a diet deficient in iodine [7]. Unfortunately, nothing is known about the agedependence of LPO concentration in human lungs. Smokers are also hit hard by the corona virus. We have previously shown that carbon monoxide, a major gaseous constituent of cigarette smoke, binds to and inactivates LPO [8] which correlates with the higher mortality of smokers. It is also estimated that two billion people worldwide suffer serious iodine insufficiency.

The mechanism by which LPO and iodide ion destroys many types of viral invaders is understood in fine detail. Here we propose a cheap method for containing COVID-19. First we hope that nutritionists and epidemiologists will study this correlation closely, especially about areas close to the seashore. Second, we encourage nutritional and health professionals to consider recommending increasing iodine intake, by either liberal use of iodized salts or consumption of more seafood, including kelp and seaweed. Such preventative measures can be quickly instituted by all and especially low income nations and the positive effects should be observed immediately. In addition, the long-term health effects of increased iodide intake should not be serious since the median longevity of the Japanese is the highest of any industrial nation. We do not think this measure will eliminate the COVID-19 pandemic but even a small decrease in the transmission rate can have immediate and positive results for everyone.

\footnotetext{
Michael L. Smith $\mathbb{D}^{1 凶}$, Sujata Sharma ${ }^{2}$ and Tej P. Singh $\mathbb{D}^{2 \bowtie}$

${ }^{1}$ Umeå University, Umeå, Sweden. ${ }^{2}$ Department of Biophysics, All India Institute of Medical Sciences, New Delhi, India. 凶email: mlsmith55@gmail.com; tpsingh.aiims@gmail.com
}

\section{REFERENCES}

1. Sharma S, Singh AK, Kaushik S, Sinha M, Singh RP, Sharma P, et al. Lactoperoxidase: structural insights into the function, ligand binding and inhibition. Int J Biochem Mol Biol. 2013;4:108-28. https://www.ncbi.nlm.nih.gov/pmc/articles/PMC3776144/ pdf/ijbmb0004-0108.pdf.

2. Bafort F, Parisi O, Perraudin JP, Jijakli MH. Mode of action of lactoperoxidase as related to its antimicrobial activity: a review. Enzym Res. 2014;2014:517164. https:// doi.org/10.1155/2014/517164.

3. Geiszt M, Witta J, Ba J, Lekstrom K, Leto TL. Dual oxidases represent novel hydrogen peroxide sources supporting mucosal surface host defense. FASEB J. 2003;17:1-14. https://doi.org/10.1096/fj.02-1104fje.

4. Patel U, Gingerich A, Widman L, Sarr D, Tripp RA, Rada B. Susceptibility of influenza viruses to hypothiocyanite and hypoiodite produced by lactoperoxidase in a cellfree system. PLoS ONE. 2018;13:e0199167. https://doi.org/10.1371/journal. pone.0199167.

5. Viswanathan V, Rani C, Ahmad N, Singh PK, Sharma P, Kaur P, et al. Structure of Yak Lactoperoxidase at 1.55 resolution. Protein J. 2021;40:8-18. https://doi.org/ 10.1007/s10930-020-09957-2.

6. Fischer AJ, Lennemann NJ, Krishnamurthy S, Pocza P, Durairaj L, Launspach JL et al. Enhancement of respiratory mucosal antiviral defenses by the oxidation of iodide. Am J Resp Cell Mol Biol. 2011;45:874-81. https://doi.org/10.1165/ rcmb.2010-0329oc.

7. Vural Z, Avery A, Kalogiros DI, Coneyworth LJ, Welham SJM. Trace mineral intake and deficiencies in older adults living in the community and institutions: a systematic review. Nutrients. 2020;12:1072. https://doi.org/10.3390/nu12041072. 
630

8. Singh AK, Smith ML, Yamini S, Ohlsson P-I, Sinha M, Kaur P, et al. Bovine carbonyl lactoperoxidase structure at $2.0 \AA$ resolution $\&$ infrared spectra as a function of $\mathrm{pH}$. Protein J. 2012;31:598-608. https://doi.org/10.1007/s10930-012-9436-3.

\section{AUTHOR CONTRIBUTIONS}

MLS, SS, and TPS have contributed equally to this letter.

\section{COMPETING INTERESTS}

The authors declare no competing interests.

\section{ADDITIONAL INFORMATION}

Supplementary Information The online version contains supplementary material available at https://doi.org/10.1038/s41430-021-00995-2.

Correspondence and requests for materials should be addressed to M.L.S. or T.P.S.

Reprints and permission information is available at http://www.nature.com/ reprints

Publisher's note Springer Nature remains neutral with regard to jurisdictional claims in published maps and institutional affiliations. 